\title{
SPORADIC CREUTZFELDT-JAKOB DISEASE
}

\section{A CLINICO-NEUROPATHOLOGICAL ANALYSIS OF NINE DEFINITE CASES}

\author{
CARLOS M. DE CASTRO COSTA*, JEAN MARIE BRUCHER**, CHRISTIAN LATERRE***
}

\begin{abstract}
The authors have analyzed clinico-neuropathologically nine cases of the definite sporadic form of Creutzfeldt-Jakob disease (CJD). All cases were female, with mean age of 62.7 years. Eighty-nine percent of the patients exhibited prodromal and initial psychiatric symptoms; definite signs of dementia, and myoclonus were present in $100 \%$ of cases. The EEG was abnormal in all cases and pseudoperiodic paroxysms were present in $56 \%$ of the patients. Their evolution time ranged from 3 to 19 months. Neuropathologically, brain and cerebellar atrophy, spongiosis, astrocytosis and neuronal loss were present in $100 \%$ of the patients. In $5(56 \%)$ of these 9 cases, prion protein $(\mathrm{PrP})$ amyloid plaques were detected in the cerebellum, by optical- and electronmicroscopy. There was a positive correlation between the number of plaques and the evolution time. The authors outline the similarities of their cases in the elderly with the new variant of CJD described in young people.
\end{abstract}

KEY WORDS: sporadic Creutzfeldt-Jakob disease, dementia, periodic EEG, neuropathology, prion protein (PrP) amyloid plaque, prion disease.

\section{Doença de Creutzfeldt-Jakob do tipo esporádico: análise clínico-neuropatológica de nove casos da forma definida}

RESUMO - Os autores analisaram, do ponto de vista clínico e neuropatológico, nove casos da forma esporádica definida da doença de Creutzfeldt-Jakob (DCJ). Todos eles eram mulheres, com idade média de 62,7 anos. Oitenta e nove por cento dos pacientes exibiram sintomas psiquiátricos prodrômicos e iniciais; sinais típicos de demência e mioclonias estavam presentes em 100\% deles. O EEG foi anormal em todos os casos e apresentou paroxismos pseudoperiódicos em 56\% dos pacientes. O tempo de evolução da doença variou de 3 a 19 meses. Do ponto de vista neuropatológico, atrofia cerebral e cerebelar, espongiose, astrocitose e perda neuronal estavam presentes em 100\% dos pacientes. Em 5 (56\%) dos 9 casos, foi evidenciada, por microscopia óptica e eletrônica, a presença de placas amilóides de proteína prion ( $\mathrm{PrP}$ ) no cerebelo. Havia correlação positiva entre o número de placas e o tempo de evolução da doença. Os autores salientam as semelhanças desses seus casos de pacientes idosos com a nova variante de DCJ descrita em pessoas jovens.

PALAVRAS-CHAVE: doença de Creutzfeldt-Jakob do tipo esporádico, demência, EEG periódico, neuropatologia, placa amilóide de proteína prion $(\operatorname{PrP})$, doença por prion.

Creutzfeldt-Jakob disease (CJD) was first described in the twenties when Creutzfeldt reported about a progressive fatal dementia associated with spasticity and myoclonus in a young patient ${ }^{1}$, and Jakob, one year later, described five similar cases of dementia associated with extrapyramidal and

*MD, MsC, PhD, Service of Neurology (Hospital University) / Laboratory of Experimental Neurology (Department of Physiology and Pharmacology), Federal University of Ceará (UFC), Brazil; **MD, PhD, Laboratory of Neuropathology, Catholic University of Louvain, Brussels, Belgium; ***MD, PhD, Clinique Saint Luc, Service of Neurology, Catholic University of Louvain, Brussels, Belgium. Aceite: 26-março-1998.

Dr. Carlos Maurício de Castro Costa - Laboratório de Neurologia Experimental e Neurofisiologia, Departamento de Fisiologia e Farmacologia/UFC - Rua Cel. Nunes de Melo 1127 - 60.430-270 Fortaleza CE - Brasil. FAX 55852439333 / 2434256. 
pyramidal signs ${ }^{2}$. CJD is the commonest form of the human transmissible spongiform encephalopathies that includes $\mathrm{Kuru}^{3}$, Gerstmann-Sträussler-Scheinker syndrome (GSS) ${ }^{4}$ and fatal familial insomnia (FFI) ${ }^{5}$. The CJD is universal and appears in all seasons; its incidence is of 1 to 2 cases per million of population. There is some higher incidence in Israelis of Libyan origin, NorthAfricans and in Slovakia. This condition has different forms: sporadic (85\%), genetic (5 to $15 \%$ ), iatrogenic and some variants (e.g. Heidenhain and ataxic forms) $)^{6-9}$.

Clinically, sporadic CJD occurs mainly in late middle age (around 60 years old), and it is exceedingly rare below the age of 30 years. Both sexes are equally affected. The prodromal symptoms include fatigue, depression, weight loss, disorders of sleep and lack of appetite. The initial symptoms are characterized by behavioral, emotional and intellective changes, visual and cerebellar changes, and confusion, with hallucination and agitation. The progression of the disease is rapid (some weeks) and, subsequently, the full clinical picture is expressed with dementia and myoclonus as main symptoms; moreover, ataxia, dysarthria and extrapyramidal changes may occur. There are some clinical variants of this classical form with predominant cerebellar ataxia ${ }^{9}$ and visual changes ${ }^{8}$. Pyramidal signs and cortical blindness may be also present. The evolution is inexorable and it progresses to akinetic mutism, torpor and coma, ending in death in most cases within 3 to 12 months. To establish the diagnosis of CJD, the following levels are determined: definite (by histological and other laboratory chemical investigation), probable and possible (both based on clinical features) ${ }^{10}$.

The complementary exams are not very helpful for the clinical diagnosis except the electroencephalogram (EEG), which may show an initial diffuse and non-specific slowing evolving, in late stage, to a picture of stereotyped high-voltage slow (1- to $2 \mathrm{~Hz}$ ) and sharp wave complexes, in a pseudoperiodic presentation on a slow and low-voltage background. This EEG pattern may be noted in 60 to $90 \%$ of these patients ${ }^{11,12}$. The CSF is in general normal. Recently, Zerr et al. reported on an elevated enolase in CSF of CJD patients ${ }^{13}$. Moreover, abnormal CSF proteins (130-131 protein ${ }^{14,15}$ and 14-3-3 protein $^{16}$ ) have been shown to be typical of CJD cases. The CT scan and MRI can show cerebral atrophy. A new variant of CJD has been recently described. Patients have an age below 45 years, have a longer duration of disease and present a predominantly psychiatric picture. Their EEG is atypical regarding the features associated with $\mathrm{CJD}^{17}$.

Pathologically, CJD is characterized by a triad of presence of spongiosis, neuronal loss and astrocytic proliferation. In some cases (10\%), amyloid deposits, called prion protein ( $\mathrm{PrP}$ ) amyloid plaques, may be observed in sporadic CJD. Immunostaining for prion protein labels them, but not plaques of the type that occur in normal aging or Alzheimer's disease ${ }^{18}$. Macroscopically, there is a diffuse cerebral and cerebellar atrophy.

Etiologically, CJD is related to abnormal prion protein (PrP) of genetic (mutation), infectious and sporadic origin. This protein was first described by Prusiner who coined the term "prion" (proteinaceous infectious particle) ${ }^{19}$. This normal protein is coded for by the PRNP gene, located in the short arm of the chromosome 20. Its pathogenic form is the result of a conformational change from genetic or unknown causes. With the aim of discussing the clinical, and mainly, the neuropathological aspects of CJD, we present nine autopsied cases. Our objective was to correlate the clinico-neuropathological findings of these nine cases of sporadic CJD with those of the literature in order to outline common and uncommon aspects.

\section{METHODOLOGY}

The autopsy material came from patients of the University Hospital of the Catholic University of Louvain (Belgium), and it was analyzed at the Laboratory of Neuropathology, under supervision of Prof. J. M. Brucher.

All cases were of the sporadic form, and in their clinical history, there were no professional or iatrogenic risk factors, as well as genetic etiology. 
For the neuropathological analysis of these cases, sections of the cerebral and cerebellar hemispheres, and different levels of the brainstem, were used.

These sections were embedded in paraffin and were stained with hematoxylin-eosin, violet cresyl, trichrome of Masson, Holzer, Spielmeyer, Red Congo, PAS, thioflavine T and oil red O. In one of the cases (Case 5), sections of the cerebellum were embedded in araldite for ultramicroscopy.

\section{CASE REPORTS}

\section{Case 1}

WM (A.1301), female, 62-years-old, presented psychiatric symptoms (particularly mutism) and gait disorders. Afterwards, involuntary choreiform movements completed her clinical picture that become more severe, with death by intercurrent disease after $41 / 2$ months of evolution. Except for a non-periodic abnormal EEG, the other exams were normal (isotopic scintilography, CSF etc).

The neuropathological findings consisted, macroscopically, of a slight cortical and basal ganglia atrophy, and microscopically, of generalized spongiosis, gliosis and neuronal atrophy, predominantly in the basal ganglia, brainstem and cerebellum. Some rare PAS positive and Red Congo stained prion protein (PrP) amyloid plaques were present in the granular, Bergmann and molecular layer, as well as in the white matter of the cerebellum.

\section{Case 2}

DL (A.2972), female, 72-years-old, had a past history of depression (2 years) and headache, and presented initially, gait disorders and mild dysarthria. Diffuse, synchronous and bilateral myoclonus was noted afterwards, and she became progressively bed-ridden and comatous. She died after six months of evolution. Her EEG was abnormal, with diffuse slow waves. The CT scan showed an important cortical atrophy.

The neuropathological examination showed macroscopically, a generalized cortical atrophy ex vacuo hydrocephalus and signs of atherosclerosis, and microscopically, spongiosis, gliosis and mild neuronal loss were present in the cerebral cortex, basal ganglia and midbrain. However, no gliosis was present in the cerebral white matter. In the brainstem, neuronal loss, gliosis and a less expressive spongiosis were present. In the cerebellum, besides diffuse gliosis, spongiosis and neuronal loss, we observed the presence of some PAS positive, Masson and Red Congo stained prion protein (PrP) amyloid plaques in the molecular, granular and Bergmann layers, and in the white matter.

\section{Case 3}

LM (A.1050), female, 62-years-old, developed a peripheral neuropathy syndrome, followed by mental deterioration, gait and visual disorders. The mental picture worsened and she developed further extrapyramidal, pseudo-bulbar signs and severe myoclonus. She became comatous afterwards, and died after eight months of clinical evolution. Her EEG was abnormal, with diffuse slow waves.

Neuropathologically, cerebral spongiosis and gliosis were present. In the medulla, a relative spongiosis and gliosis were present, as well as some cell atrophy. In the cerebellum, besides spongiosis, gliosis and slight cellular loss, we noted some prion protein (PrP) amyloid plaques in the Bergmann, molecular and granular layers, as well as in the white matter.

\section{Case 4}

VZMH (A.798), female, 63-years-old, had a previous history of psychiatric disorders. She lived alone, although she had some dogs. Afterwards, she presented gait difficulty and frequent falls, followed by a progressive picture of aphasia-agnosia, apraxia, stiffness of the limbs, dysphagia and upper extremity myoclonus. Later on, she developed status epilepticus, with subsequent coma and death, after 11 months of clinical evolution. Her EEG showed bilateral, synchronous and asynchronous repetitive pseudoperiodic paroxysms of 3 to $6 \mathrm{c} / \mathrm{sec}$ sharp waves.

Neuropathological examination showed important cerebral atrophy, and microscopically, a diffuse neuronal loss and gliosis of the cerebral cortex and basal ganglia, and a very slight diffuse gliosis of the white matter. In the pons, a slight diffuse spongiosis and gliosis were present. In the cerebellum, a slight diffuse spongiosis, gliosis and areas of demyelination were present and several prion protein ( $\mathrm{PrP}$ ) amyloid plaques in the white matter and granular, Bergmann and molecular layers were noticed. Morphologically, they were rounded with peripherally radially-oriented fibrils. They were eosinophil to hematoxyline-eosine, blueish to Masson, slightly argentophil, slightly PAS positive, Red Congo positive with yellow-green dychroism to polarized light. They presented as well a slight green fluorescence to thioflavine $\mathrm{T}$. 


\section{Case 5}

CMT (A.3113), female, 56-years-old, presented depressive symptoms, and posteriorly, developed dementia of rapid evolution, associated with aphasia, apraxia, ataxia and progressive global hypertonia, as well as diffuse myoclonus and cortical blindness. She became progressively bed-ridden and died from intercurrent disease after 19 months of clinical evolution. The pneumoencephalogram showed an accentuated cortical atrophy. The EEG presented variable paroxysms of high voltage delta waves, followed by bi- and tri-phasic pseudoperiodic sharp waves, with a frequency of about $2 \mathrm{c} / \mathrm{sec}$.

The neuropathological findings consisted macroscopically, of diffuse cerebral and cerebellar atrophy, and microscopically, diffuse cerebral neuronal loss, spongiosis and severe gliosis in the cerebral cortex, basal ganglia and midbrain. Slight demyelination was present in the cerebral white matter. The brainstem presented a relative gliosis and neuronal atrophy up to the high cervical level of the spinal cord (C1). In the cerebellum we noticed a relative spongiosis, gliosis and neuronal loss, and slight demyelination of the white matter. In the molecular, Bergmann and granular layers, and in the white matter, we noted the presence of very abundant prion protein (PrP) amyloid plaques. They were rounded, sometimes clustered, and of radially-oriented fibrillar structure. They were Red Congo and PAS positive, presented yellow-green dychroism to polarized light, and green fluorescence to thioflavine T. They were mildly positive to Jabonero and blue Alcian staining.

\section{Case 6}

VG (A.3118), female, 72-years-old, presented a progressive spasticity of the right side of the body, followed by left side spasticity. Her condition rapidly deteriorated to akynetic mutism. The neurological examination showed a generalized hypertonia and hyperreflexia, predominant in the right side. Her EEG was abnormal, with high amplitude triphasic waves and pseudoperiodic paroxysms. The patient died after three months of pulmonary infection.

The neuropathological findings showed a brain and cerebellum with moderate atrophy. Microscopically, spongiosis and gliosis in the cerebral cortex (2nd and 3rd layer) and in the cerebellum (only in the molecular layer), as well as a neuronal rarefaction of the cortex were noted. There was also spongiosis and gliosis of the caudate nucleus, putamen and thalamus. In addition some corpora amylacea were present with no amyloid plaques.

\section{Case 7}

TM (A.2694), female, 48-years-old, presented dysphoria, apathy, loss of interest and initiative, memory deficits and temporal disorientation. Later, she complained of right hypoacusia, and then of visual impairment, with ataxia and myoclonus of hands and legs. Some days before her admission, she presented aphasia and, on admission, we detected dysarthria, apathy and dysphoria. Her gait was ataxic, with positive Romberg, dysmetria predominant on the right side of the body and brisk reflexes in the lower limbs. Her EEG presented pseudoperiodic paroxystic complexes, and the CSF and isotopic scintilography were normal. The patient died after five months of evolution.

The neuropathological examination revealed macroscopically, slight cortical atrophy with slight hydrocephalus, and microscopically, spongiosis, gliosis and neuronal loss predominant in the cerebral cortex and striatum. There was also moderate spongiosis of the molecular layer and gliosis of the white matter, but no amyloid plaques in the cerebellum.

\section{Case 8}

DMG (A.2732), female, 63-years-old, had a slight depressive state as first symptom and some difficulty in finding words. One month later, she presented a slight right hemiparesia. A CT scan performed at that time was normal. The EEG was abnormal, with diffuse slow waves predominant on the left. Posteriorly, a demential state progressed with apraxia, incontinence and bilateral myoclonus. At that time, the EEG showed pseudoperiodic paroxysms of slow waves. She died after six months of evolution.

The neuropathological examination revealed macroscopically, an important cerebral atrophy with proeminent hydrocephalia, and microscopically, a diffuse cortical spongiosis and gliosis, with massive neuronal loss. This was equally present in the basal nuclei. The cerebellum was slightly atrophic, with spongiosis of the molecular layer and no amyloid plaques.

\section{Case 9}

BI (A.2491), female, 66-years-old, had as first symptoms, depression and convulsions that evolved over a long period into impairment of equilibrium, gait disorders, weakness in the legs and difficulty of speech. Later, she presented a confusional state. On admission she was confused, somnolent and dysarthric, with an important 
Table 1. Clinical aspects of nine cases of sporadic Creutzfeldt-Jakob disease.

\begin{tabular}{|c|c|c|c|c|c|c|c|c|c|}
\hline \multirow[b]{2}{*}{ Aspects } & \multicolumn{9}{|c|}{ Patients } \\
\hline & WM & DL & LM & VZMH & CMT & VG & $\mathrm{TM}$ & DMG & BI \\
\hline Age $^{1}$ (years) & 62 & 72 & 62 & 63 & 56 & 72 & 48 & 63 & 66 \\
\hline Sex & $\mathrm{F}$ & $\mathrm{F}$ & $\mathrm{F}$ & $\mathrm{F}$ & $\mathrm{F}$ & $\mathrm{F}$ & $\mathrm{F}$ & $\mathrm{F}$ & $\mathrm{F}$ \\
\hline Evolution $^{2}$ (months) & $41 / 2$ & 6 & 8 & 11 & 19 & 3 & 5 & 6 & 6 \\
\hline $\begin{array}{l}\text { Prodromal symptoms } \\
\text { Psychiatric disorders } \\
\text { (mutism, depression, } \\
\text { dysphoria) }\end{array}$ & + & + & + & + & + & - & + & + & + \\
\hline \multicolumn{10}{|l|}{ Symptoms at onset } \\
\hline Gait disorders & - & + & + & + & - & + & - & - & + \\
\hline Dysarthria & - & + & - & - & - & - & - & - & + \\
\hline Visual disorders & - & - & + & - & - & - & - & - & - \\
\hline Apathy & - & - & - & - & - & - & + & - & - \\
\hline Disorientation & - & - & - & - & - & - & + & - & - \\
\hline Dysphagia & - & - & - & - & - & - & - & - & - \\
\hline Motor symptoms & + & - & - & - & - & - & - & + & + \\
\hline \multicolumn{10}{|l|}{ Definite symptoms } \\
\hline Dementia & + & + & + & + & + & + & + & + & + \\
\hline Myoclonus & - & + & + & + & + & - & + & + & - \\
\hline $\begin{array}{l}\text { Motor symptoms } \\
\text { (hypertonia, } \\
\text { hyperreflexia, ataxia) }\end{array}$ & - & - & + & + & + & + & + & + & + \\
\hline Cortical blindness & - & - & - & - & + & - & - & - & - \\
\hline Coma & - & + & - & - & - & - & - & - & - \\
\hline EEG & $\mathrm{Ab}$ & $\mathrm{Ab}$ & $\mathrm{Ab}$ & $\mathrm{PP}$ & PP & $\mathrm{PP}$ & PP & PP & $\mathrm{Ab}$ \\
\hline
\end{tabular}

Legend: ${ }^{1}$ Mean 62.7 years; ${ }^{2}$ Mean 7.5 months (range $=3$ to 19 ); Ab, abnormal; PP, pseudoperiodic.

bilateral cerebellar syndrome. Later on she presented a slight left hemiparesis. Her EEG was abnormal with slow background. She died of heart collapse after six months of evolution.

From the neuropathological point of view, there was a slight senile atrophy of the brain. Microscopically, there was a prominent spongiosis of the cerebral cortex, striatum and thalamus, and patchy areas of gliosis and microglial proliferation. Moreover, there was a diffuse neuronal loss. The cerebellum exhibited a diffuse spongiosis of the molecular layer with no amyloid plaques.

\section{In summary}

All patients were women, with age ranging from 48 to 73 years (mean age 62.7). The clinical evolution of these patients had an average duration of 7.5 months (range 3 to 19 months). Almost all patients had initial psychiatric prodromic symptoms $(89 \%)$, followed by gait disorders $(50 \%)$, motor symptoms $(22 \%)$, dysarthria (22\%), visual disorders $(11 \%)$, apathy $(11 \%)$ and disorientation $(11 \%)$. All patients presented a full clinical picture with dementia (9/9) and myoclonus (8/9), and some of them additionally presented motor symptoms (7/ 9), cortical blindness (1/9) and coma (1/9) (Table 1). Fifty-sex percent of the patients had pseudoperiodic EEG and $44 \%$ had abnormal EEG, with diffuse slow waves.

From the neuropathological point of view, $89 \%$ of the cases showed brain atrophy and $45 \%$ also had cerebellar atrophy. Microscopically, all cases exhibited spongiosis, astrocytosis and neuronal loss affecting the cerebrum (Fig 1) and cerebellum, and, in some rare cases, microglial proliferation (11\%), demyelination in the brain white matter (34\%) and amyloid plaques in $56 \%$ of the cases (Table 2). 


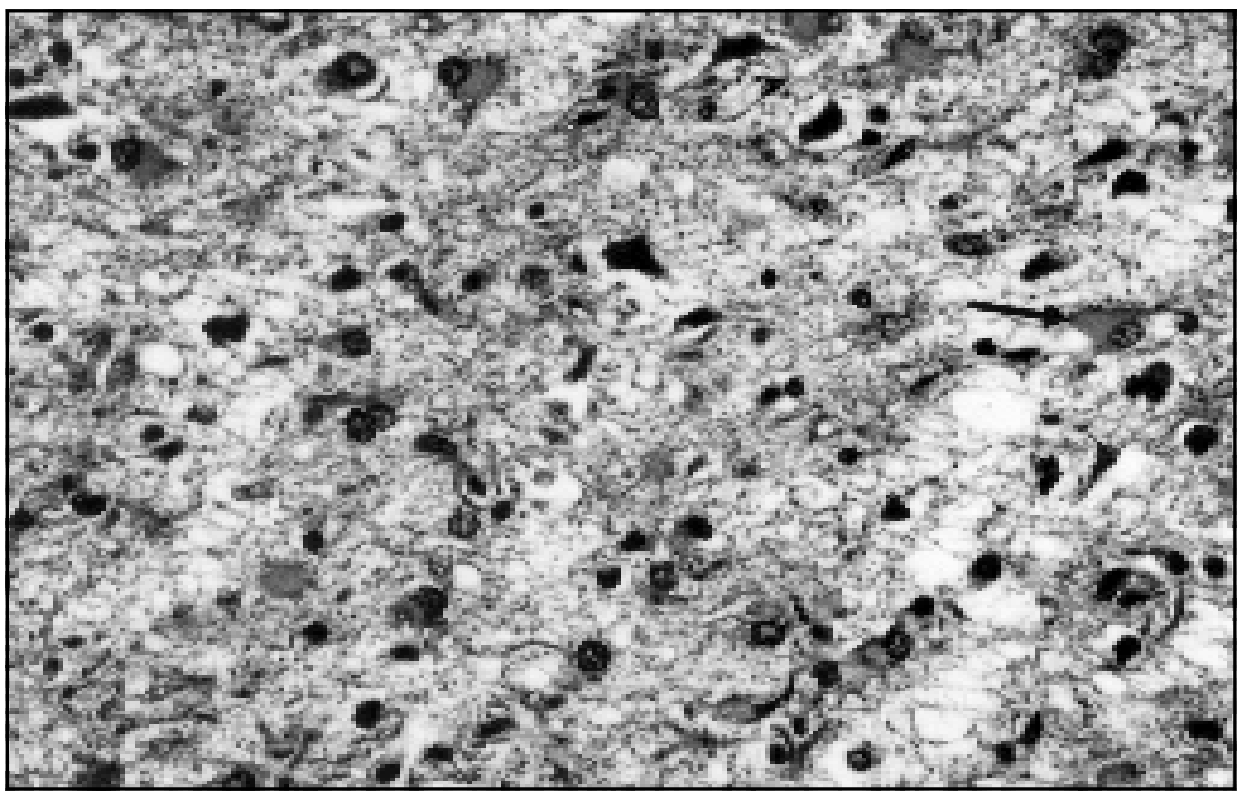

Fig 1. Spongiosis and gliosis of parietal cortex (Masson x 330).

Table 2. Neuropathological findings in nine cases of sporadic Creutzfeldt-Jakob disease.

\begin{tabular}{|c|c|c|c|c|c|c|c|c|c|}
\hline \multicolumn{10}{|c|}{ Patients } \\
\hline Findings & WM & $\mathrm{DL}$ & LM & VZMH & CMT & VG & $\mathrm{TM}$ & DMG & $\mathrm{BI}$ \\
\hline \multicolumn{10}{|l|}{ Macroscopical } \\
\hline Brain atrophy & + & + & NR & + & + & + & + & + & + \\
\hline Cerebellum atrophy & - & - & - & - & + & + & - & + & + \\
\hline \multicolumn{10}{|l|}{ Microscopical } \\
\hline Spongiosis & + & + & + & + & + & + & + & + & + \\
\hline Astrocytosis & + & + & + & + & + & + & + & + & + \\
\hline Neuronal loss & + & + & + & + & + & + & + & + & + \\
\hline Microglial prolif. & - & - & - & - & - & - & - & - & + \\
\hline Demyelination & - & - & - & + & + & - & - & + & - \\
\hline $\begin{array}{l}\text { Prion protein } \\
\text { (PrP) Plaques: }\end{array}$ & & & & & & & & & \\
\hline Cerebellum & + & + & + & + & + & - & - & - & - \\
\hline
\end{tabular}

Legend: NR, not reported; prolif, proliferation.

These prion protein $(\operatorname{PrP})$ amyloid plaques were found in the cerebellum, and were composed of radiallydisposed fibrillary structures sometimes with a dense core (Fig 2). They exhibited histochemical characteristics of amyloid substance: the plaques were Red Congo positive and showed dychroism to polarized light. The ultramicroscopical analysis of Case 5 showed that the plaques were composed of tubular filaments, with an exterior diameter of 7 to $11 \mathrm{~nm}$ and irregular transverse striation, confirming their amyloid nature (Fig 3). Moreover, there was a positive $(r=0,91)$ ( Pearson product moment correlation coefficient. Ferguson, 1956) and significant $(\mathrm{p}<0.05)$ (Table F: Critical values of the correlation coefficient. Ferguson, 1956) correlation between the number of plaques and the clinical evolution of the disease. 


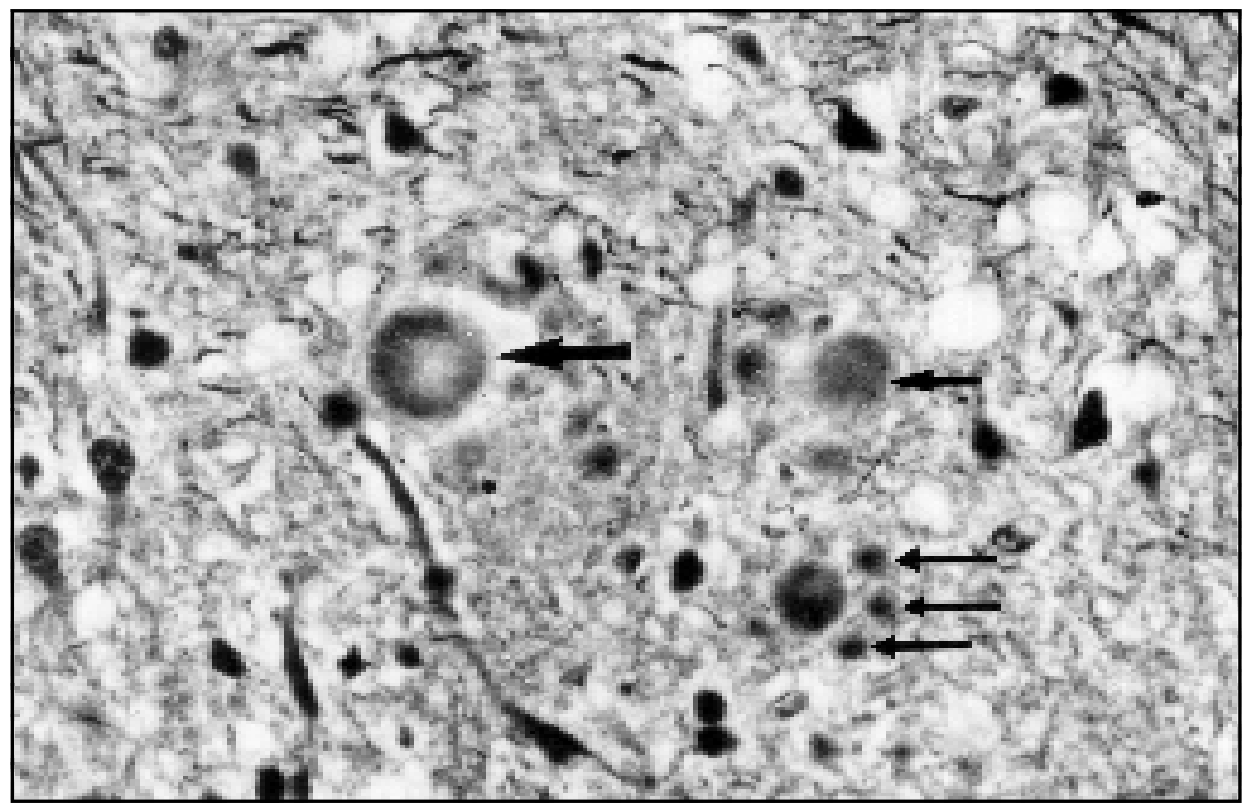

Fig 2. Several prion protein $(\mathrm{PrP})$ amyloid plaques of different sizes in the molecular layer of the cerebellum. Some of them show a radially-oriented fibrillar structure (Jabonero $x 530$ ).

\section{DISCUSSION}

The cases we have described belong to the sporadic form of Creutzfeldt-Jakob disease (CJD), with classical demographic and clinical characteristics, except for the predominance of psychiatric symptomatology, abundance of plaques and long evolution similar to the new variant recently described $^{17}$. The origin of the sporadic form, which represent $85 \%$ of CJD cases, is still unknown. The familial forms are autosomal dominant disorders associated with coding mutations in the prion protein gene (PRNP), and the iatrogenic CJD and Kuru are the infectious forms, respectively related to corned graft, use of human cadaveric growth hormone etc (iatrogenic CJD) and cannibalism (Kuru). The sporadic form also exhibits accumulation of abnormal PrP protein, and a significant correlation between valine at codon 129 of the prion protein gene and the presence of plaques in this form has been shown ${ }^{20}$. Regarding age, all cases occurred at the usual time of onset of the disease. However, there have been reports of young cases (below 45 years old) that represent a new variant of prion disease in its clinical presentation (behavioral, psychiatric and early ataxia) and longer duration, similar to $\mathrm{Kuru}^{17,21}$. This new variant may possibly be related to exposure to bovine prions ${ }^{17,22}$. Clinically, some of our cases exhibited a longer evolution, and all patients showed prodromal psychiatric symptoms and definite signs of dementia and myoclonus, as well as ataxia. These symptoms were correlated with the neuropathological findings. In our series, all cases presented EEG abnormalities, and in 56\% of them, there were the typical pseudoperiodic paroxysms of bilateral synchronous sharp waves, similar to those described in the literature although not the frequency of 60 to $90 \%{ }^{23,24}$. However, $44 \%$ of the EEGs of our cases were not typical of CJD. These aspects highlight the similarity between these cases and the new variants recently described ${ }^{17}$. Neuroimaging studies, when performed, showed brain atrophy. The CSF was normal.

The neuropathological findings of our cases are in keeping with the literature regarding macroscopical brain and cerebellum atrophy, and microscopical evidence of spongiosis, astrocytosis, 


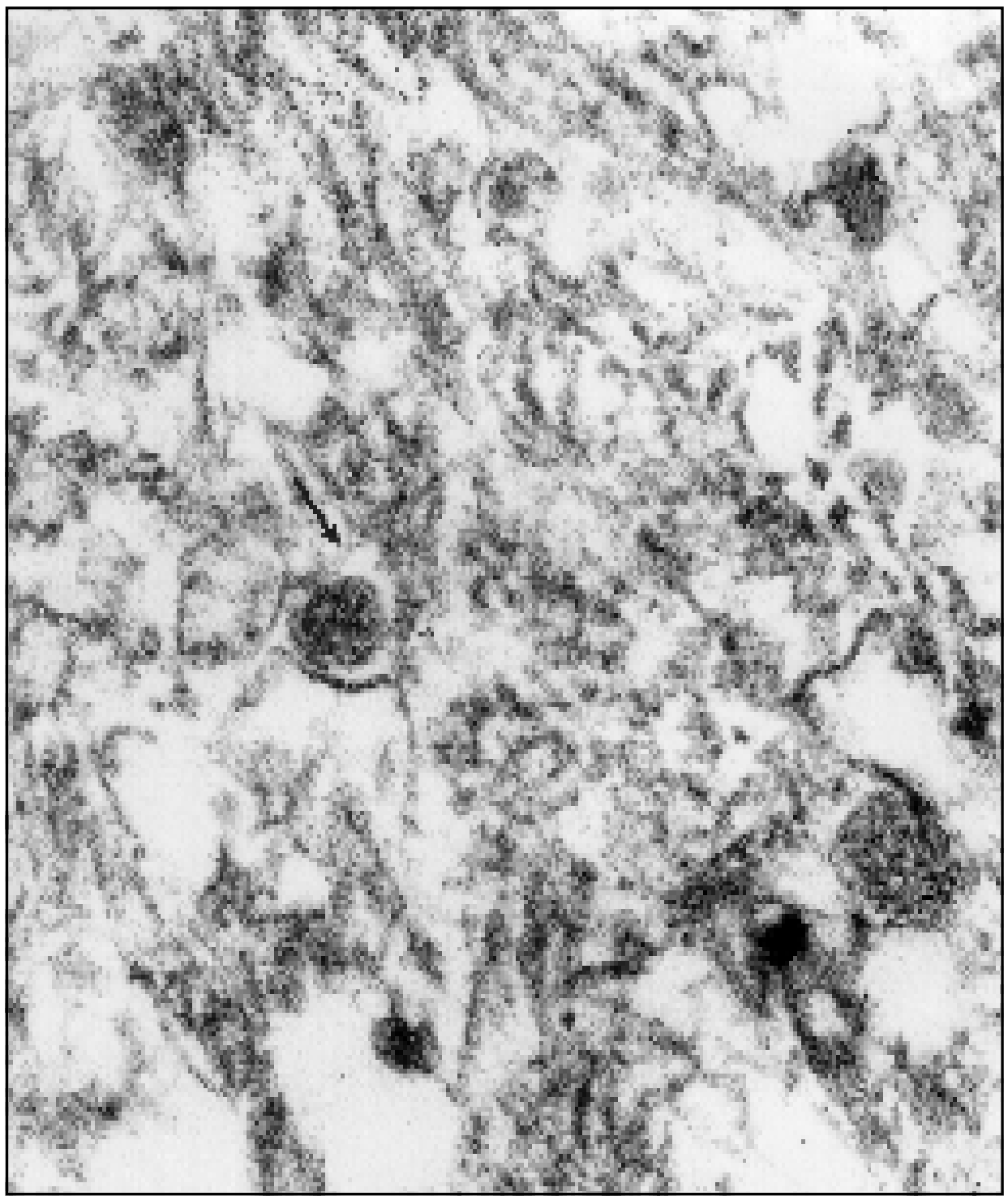

Fig 3. Several tubular filaments ( 7 to $11 \mathrm{~nm}$ ) distributed in all directions and presenting an irregular transverse striation $(x$ 150,000).

neuronal loss and amyloid plaque formation ${ }^{25}$. However, some of our cases had shown histological changes in the brainstem (Cases 1 to 5) and spinal cord (Case 5). The involvement of spinal cord is rare, but it has been shown recently, thus suggesting a potential peripheral route of exposure to the sporadic CJD causing agent. Moreover, this may be indicative of a possible means of transmission of bovine spongiform encephalopathies to the human population ${ }^{26,27}$.

It has been reported that amyloid plaques occur in around 10 to $15 \%$ of CJD cases, mainly in the cerebellum but also in the cerebral cortex and basal ganglia ${ }^{28-30}$. In our series, amyloid plaque occurrence was higher $(56 \%)$, with a strong predominance in the cerebellum, and this has been one 
of the main aspects of this study. The number of plaques could be considered as an evolutive marker in our cases. These plaques are mainly present in GSS. In contrast to the compact plaques of CJD, those of GSS syndrome are multicentric and should be distinguished from the neuritic plaques of Alzheimer's disease ${ }^{18,30}$.

The amyloid plaques present in the cases of CJD are largely composed of polymerized PrP molecules ${ }^{31}$. This polymerized form has straight fibers of various diameters, which may represent the basic element in the formation of amyloid plaques. These amyloid plaques are one of the major neuropathological features of transmissible spongiform encephalopathies in animals and man. They react immunohistochemically to antibodies against prion protein ${ }^{27}$, but not to antibodies against BA4 amyloid ${ }^{18}$. These amyloid plaques are thus an accumulation of abnormal prion protein $\left(\mathrm{PrP}^{\mathrm{SC}}\right.$ or $\mathrm{PrP}^{\mathrm{CID}}$ ). This abnormal protein has a molecular mass of 27 to $30 \mathrm{kDa}$ and it is virtually identical to part of a glycoprotein $\left(\operatorname{PrP}^{\mathrm{C}}\right)$ formed naturally in the mammalian brain (normal $\mathrm{PrP}$ ). The normal form $\left(\operatorname{PrP}^{\mathrm{C}}\right)$ has a high content of $\alpha$-helices and is readily digested by proteolytic enzymes, while $\mathrm{PrP}^{\mathrm{SC}}$ or $\mathrm{PrP}^{\mathrm{CID}}$ has a $\beta$-sheet conformation, is resistant to proteolysis and accumulates to form the typical amyloid fibrillar plaques ${ }^{32}$.

The clinical presentation of our cases, and the presence of abundant prion protein plaques in most of them, leads us to speculate that these cases might be examples of the new variant CJD in old people or examples of evolutive classical cases, with an onset similar to the new variant in young people. Similar but iatrogenic old cases have been recently described ${ }^{33}$.

Acknowledgment - We would like to thank Prof. Jean Marie Brucher for his expert orientation in the neuropathological analysis of the cases, Ms. Marion Mative and Mr. Yves de Craeye for their skilled technical aid, Ms. Françoise Wouters for her secretarial assistance, and Mr. Sílvio Costa for his accurate typewriting of this text on a wordprocessor.

\section{REFERENCES}

1. Creutzfeldt HG. Uber eine eigenartige herdformige Erkrankung des Zentralnervensystem. Z Gesam Neurol Psychiatr 1920;57:1-18.

2. Jakob A. Uber eigenartige Erkrankung des Zentralnervensystem, mit bemerkenswerten anatomischen Befunde. Z Gesam Neurol Psychiatr 1921;64:47-228.

3. Gajdusek DC, Zigas V. Degenerative disease of the central nervous system in New Guinea. N Engl J Med 1957;257:974.

4. Gerstmann J, Sträussler E, Scheinker J. Uber eine eigenartige hereditair-familiare Erkrankung des Zentralnervensystems. Z Neurol 1936;154:736-762.

5. Medori R, Tritschler H-J, Leblanc A, et al. Fatal familial insomnia: a prion disease with a mutation at codon 178 of the prion protein gene. N Engl J Med 1992;326: 444-449.

6. Cathala F, Brown P, Chatelain J. Maladie de Creutzfeldt-Jakob en France: intêret des formes familiales. Presse Med 1986;15:379.

7. Masters CL, Harris JO, Gajdusek C. Creutzfeldt-Jakob disease: patterns of worldwide occurrence and the significance of familial and sporadic clustering. Ann Neurol 1979;5:177.

8. Heidenhain A. Klinische und anatomische Untersuchungen uber eine eigenartige organische Erkrankung des Zentralnervesystems im Praesenium. Z Gesamte Neurol Psychiatr 1929;118:49.

9. Brownell B, Oppenheimer DR. An ataxic form of subacute presenile polioencephalopathy (Creutzfeldt-Jakob disease). J Neurol Neurosurg Psychiatry 1965;20:350-361.

10. Kretzschmar HA, Ironside JW, DeArmond SJ, Tateishi J. Diagnostic criteria for sporadic Creutzfeldt-Jakob disease. Arch Neurol 1996;53:913-920.

11. Brown P. EEG findings in Creutzfeldt-Jakob disease. JAMA 1993;269:3168.

12. Cathala F, Baron H. Clinical aspects of Creutzfeldt-Jakob disease. In Prusiner SB, McKinley MP (eds.). Prion: novel infectious pathogens causing scrapie and Creutzfeldt-Jakob disease. Orlando: Academic Press, 1987:467-509.

13. Zerr I, Bodemer M, Recker S, et al. Cerebrospinal fluid concentration of neuron-specific enolase in diagnosis of CreutzfeldtJakob disease. Lancet 1995;345:1609-1610.

14. Zerr I, Bodemer M, Otto M, et al. Diagnosis of Creutzfeldt-Jakob disease by two-dimensional gel electrophoresis of cerebrospinal fluid. Lancet 1996;348:846-849.

15. Lee KH, Harrington MG. Premortem diagnosis of Creutzfeldt-Jakob disease by cerebrospinal fluid analysis. Lancet 1996;348:887.

16. Zerr I, Bodemer M, Gefeller O, et al. Detection of 14-3-3 protein in the cerebrospinal fluid supports the diagnosis of Creutzfeldt-Jakob disease. Ann Neurol 1998;43: 32-40.

17. Will RG, Ironside JW, Zeidler M, et al. A new variant of Creutzfeldt-Jakob disease in the UK. Lancet 1996;347:921-925. 
18. Prusiner SB, Hsiao KK. Human prion diseases. Ann Neurol 1994;35:385-395.

19. Prusiner SB. Novel proteinaceous infectious particles cause scrapie. Science 1982; 216(9):136-144.

20. Pickering-Brown SM, Mann DMA, Owen F et al. Allelic variants in apolipoprotein E and prion protein genotype related to plaque formation and age of onset in sporadic Creutzfeldt-Jakob disease. Neurosci Lett 1995;187:127-129.

21. Collinge J, Rossor M. A new variant of prion disease. The Lancet 1996;347:916-917.

22. Ironside JW. Prion diseases: update on Creutzfeldt-Jakob disease. Neuropathol Appl Neurobiol 1996;22:446.

23. Aminoff MJ. Electrophysiologic studies of the central and peripheral nervous systems. In Fauci et al. (Eds). Harrison's Principles of Internal Medicine. New York: McGraw-Hill, 1998:2282-2283.

24. Chiofalo N, Fuentes A, Galvez S. Serial EEG findings in 27 cases of Creutzfeldt-Jakob disease. Arch Neurol 1980;37:143.

25. Bell JE, Ironside JW. Neuropathology of spongiform encephalopathies in humans. Br Med Bull 1993;49(4):738-777.

26. Goodbrand IA, Ironside JW, Nicolson D, Bell JE. Prion protein accumulation in the spinal cords of patients with sporadic and growth hormone associated Creutzfeldt-Jakob disease. Neurosci Lett 1995;183:127-130.

27. Sutherland K, Goodbrand IA, Bell JE, Ironside JW. Objective quantification of prion protein in spinal cord of cases of Creutzfeldt-Jakob disease. Anal Cell Pathol 1996;10:25-35.

28. Billete de Villemeur T, Fournier J-G, Robain O, Escaig-Haye F, Brown P. Electronmicroscopic detection of prion-proteinpositive fibres in brain from iatrogenic Creutzfeldt-Jakob disease. The Lancet 1995;345:861-862.

29. Bastian FO. Creutzfeldt-Jakob disease and other transmissible human spongiform encephalopathies. St. Louis: Mosby Year Book, 1991.

30. Azzarelli B, Muller J, Ghetti B, Dyken M, Conneally PM. Cerebellar plaques in familial Alzheimer's disease (GerstmannSträussler-Scheinker variant?). Acta Neuropathol (Berl) 1985;65:235-246.

31. Kitamoto T, Mohri S, Tateishi J. Organ distribution of proteinase-resistant prion protein in humans and mice with CreutzfeldtJakob disease. J Gen Virol 1989;70: 3371-3379.

32. Hart CA. Prion disease. Br J Hosp Medic 1996;56:64-65.

33. Kopp N, Streichenberger N, Deslys JP, Laplanche JL, Chazot G. Creutzfeldt-Jakob disease in a 52-years-old woman with florid plaques. Lancet 1996;348:1239-1240. 